\title{
Analysis of Spinel Based Inclusions During the Last Stage of The Steelmaking Process of SAE 52100
}

\author{
Julio Aníbal Morales Pereira* (D), Vinicius Cardoso da Rocha ${ }^{a}$, Pedro Cunha Alvesa, \\ Wagner Viana Bielefeldta, Antônio Cezar Faria Vilela ${ }^{a}$ \\ ${ }^{a}$ Universidade Federal do Rio Grande do Sul (UFRGS), Departamento de Metalurgia (DEMET), \\ Porto Alegre, RS, Brasil
}

Received: October 8, 2019; Revised: February 15, 2020; Accepted: March 10, 2020

\begin{abstract}
$\mathrm{Al}_{2} \mathrm{O}_{3}$ (alumina) and $\mathrm{MgO} \cdot \mathrm{Al}_{2} \mathrm{O}_{3}$ (spinel) inclusions cause valve obstruction (clogging) in continuous casting and can deteriorate the quality of the final product. In this context, industrial heats of the bearing steel SAE 52100 was examined. Samples were collected in the final steps of the steelmaking process, both after vacuum treatment and during continuous casting. A scanning electron microscope (SEM) equipped with a energy-dispersive spectrometer (EDS) and automated particle characterization analysis was used to characterize the inclusions present in the steel samples. Thermodynamic calculations were performed with the commercial software FactSage ${ }^{\mathrm{TM}}$ 7.2. Based on thermodynamic predictions, parameters such as solid fraction, liquid fraction, $\mathrm{MgO}$ saturation point of the slags, content of dissolved elements in steel $(\mathrm{Al}, \mathrm{Mg}, \mathrm{Ca}, \ldots)$ and the construction of a phase stability diagram were determined. The results in this study showed a tendency for increase in $\mathrm{MgO}$ content in the inclusions with the decrease of $\% \mathrm{FeO}$ and $\mathrm{SiO}_{2}$ contents in the slag, an increase of binary basicity $\left(\% \mathrm{CaO} / \% \mathrm{SiO}_{2}\right)$. It is verified that the $\mathrm{MgO}$ contents in the slag were close to the saturation, increasing the probability for the formation of inclusions rich in $\mathrm{MgO}$ and/or spinel. On the other hand, stability diagrams confirm the formation of spinel inclusions for each of the heats analyzed. During the final step of the steelmaking process, there is a tendency for re-oxidation, which is verified by an increase in the density of inclusions (or total oxygen TO values).
\end{abstract}

Keywords: steelmaking, bearing steels, inclusions, re-oxidation, slags.

\section{Introduction}

Bearing steels are known for their quality and performance, guaranteed by high toughness and low levels of non-metallic inclusions. In addition, these steels have good mechanical strength and high fatigue life. These characteristics result in mechanical properties are achieved through a rigid steelmaking process in the melt shop, where the liquid steel undergoes a series of refining reactions, including the removal of non-metallic inclusions (NMIs) through their transport, absorption and dissolution to the slag phase ${ }^{1-11}$. However, although all efforts made in the steel industry to strictly meet the cleanliness requirements (clean steels), it is still observed in the metallurgical processing of this steel, the residual of alumina $\left(\mathrm{Al}_{2} \mathrm{O}_{3}\right)$ inclusions, which are the product of deoxidation in Al-killed steels and spinel $\left(\mathrm{MgO} \cdot \mathrm{Al}_{2} \mathrm{O}_{3}\right)$ inclusions, formed by the presence of $\mathrm{Mg}$ in the liquid steel. Both are considered to be harmful to the mechanical properties of the steels ${ }^{12-14}$.

As described by Costa and Silva ${ }^{1}$, while there is still controversy concerning the effect of the individual types of NMIs on the fatigue life of bearing steels, some general agreement seems to prevail regarding calcium aluminates and spinel inclusions that are detrimental. The solid phases of higher occurrence in the inclusions are spinel, calcium

*e-mail:juliolasid@yahoo.com.br. aluminate and corundum. The formation of these inclusions is a sign that their modification was unfinished. The control of slag composition is always one of the key points in controlling NMIs in bearing steels. Furthermore, the reversion of magnesium from the slag, which may lead to the formation of spinel inclusions, must be avoided.

Following the same idea in regards to the effect of slags, Okuyama et al. ${ }^{15}$ showed a strong relationship between slag parameters and the control of NMIs, indicating that an increase of basicity and the $\mathrm{CaO} / \mathrm{Al}_{2} \mathrm{O}_{3}$ ratio in the slag favors the formation of spinel inclusions in steel. Park and Todoroki ${ }^{16}$ also report some alternatives (direct or indirect supply of calcium, reduction of basicity $\left(\% \mathrm{CaO} / \% \mathrm{SiO}_{2}, \% \mathrm{CaO} / \% \mathrm{Al}_{2} \mathrm{O}_{3}\right.$ ratio) and content of $\mathrm{Al}_{2} \mathrm{O}_{3}$ and $\mathrm{MgO}$ in the slag, minimizing melt re-oxidation in conjunction with low $\mathrm{Al}$ content and others) for better control of spinel during the steelmaking process. According to Yang et al. ${ }^{17}$, modification of inclusions with calcium is not always effective, generating partly modified inclusions with spinel nuclei, which are detrimental to the properties of the steel due to their low deformability during hot rolling. Finally, studies on the formation of spinel inclusions have been reported through thermodynamic calculations of phase stability diagrams of the $\mathrm{Al}-\mathrm{Mg}-\mathrm{O}$ system in steel to predict the formation of inclusions ${ }^{12,18-23}$. 
The present study focuses on the analysis of slag composition $\left(\% \mathrm{FeO}\right.$ content, $\% \mathrm{SiO}_{2}$ content, binary basicity, liquid fraction and saturation point in $\mathrm{MgO}$ ), steel composition, characterization and modification by calcium of inclusions during the last stages of the refining process of the SAE 52100 obtained from industry. Based on thermodynamic calculations, equilibrium diagrams and fundamental theory found in the literature, we aim to contribute to a better understanding and increase the control of cleanliness (re-oxidation) and quality of this steel.

\section{Materials and Methods}

\subsection{Sampling and analysis techniques}

The sampling methodology follows the experimental procedure adopted in previous studies ${ }^{24-28}$. Figure 1 ilustrates the sampling process described.

During the manufacturing process the stages were as follows: electric arc furnace (EAF) - processing time about 60 minutes, ladle furnace (LF) - processing time about 50 minutes, vacuum degassing tank type (VD) - processing time about 20 minutes (pressure 1×10-4 bar; average gas flow rate $125 \mathrm{Nl} / \mathrm{min}$ ) and solidification in a continuous casting (CC) machine with three strands. The average temperature at the end of the secondary refining process and at the beginning of the casting is $1550{ }^{\circ} \mathrm{C}$. The deoxidation process applied includes aluminum (Al) addition during steel tapping and at the end of the vacuum degassing (VD). Instead of adding CaSi wire for inclusion treatment, the modification of inclusions were controlled by an indirect supply of calcium via slag phase to the metal during the ladle refining process. A total of nine (9) heats of SAE 52100 were monitored in this study. Steel samples were collected during the final step of the vacuum degassing treatment (samples $\mathrm{X} 1$ ), and during the continuous casting process at the tundish (samples X2). Furthermore, during the vacuum degassing step, samples of slag (samples Y1) were simultaneously collected in the same $\mathrm{CC}$ sequencing. The chemical compositions of the steel samples were determined by optical emission spectroscopy (ARL 3560 spectrometer) and total oxygen (TO) using LECO TC-436. The [Mg] content in the bath was not measured. The collected steel samples were prepared metallographically. Afterwards, the chemical composition, morphology, size and number of inclusions in the samples were determined using a scanning electron microscope (SEM-ASPEX Explorer) with automated feature analysis (AFA) and equipped with a dispersive energy spectrometer (EDS). The beam is centered on the inclusion using a rotating chord algorithm and an EDS spectrum is collected. During acquisition,

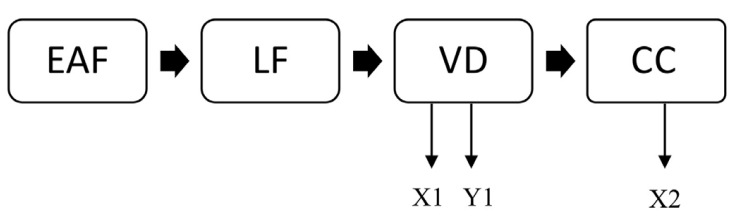

Figure 1. Sampling process in the steelmaking route. Samples: steel $\mathrm{X}(1,2), \operatorname{slag}(\mathrm{Y} 1)$. the EDS spectrum is quantified and the metric (including average, maximum and minimum diameters, orientation and centroid) and quantification data are used to classify the feature according to user defined rules. A classification rule file is a series of Boolean expressions that define a set of classes (a list of elements in which you are interested) into which each feature is assigned ${ }^{29}$.

For this study, the analyzed area of the steel samples varied in the range of 49.7 to $66.9 \mathrm{~mm} 2$. Inclusions smaller than $2.5 \mu \mathrm{m}$ were disregarded, since, for inclusionary control of bearing steel, inclusions larger than $4 \mu \mathrm{m}$ are considered 8,25,28. The operating parameters were an accelerating voltage of $20 \mathrm{keV}, 16-18 \mathrm{~mm}$ focus, backscattering mode, inclusion diameter detection limit was size $4 \mu \mathrm{m}$ and maximum size $225 \mu \mathrm{m}$. Time process EDS: $1 \mathrm{~s}$ (min.) and $2 \mathrm{~s}$ (máx). The slag compositions were measured by X-ray fluorescence spectroscopy (FRX).

\subsection{Thermodynamic calculations}

Thermodynamic calculations were performed with the aid of a computational thermochemical software package named FactSage $^{\mathrm{TM}} 7.2^{30}$. In order to determine the solid fraction, liquid fraction and $\mathrm{MgO}$ saturation of the slags used, the chemical composition of the final slag (sample Y1) for each heat was taken. The temperature of $1550^{\circ} \mathrm{C}$ was considered and the FactPS and FToxid databases were selected ${ }^{29}$. This same methodology was also used to verify the influence of the increase of the silica in the slag.

In the Equilibrium module and from the chemical composition of the steel (sample X2), including the total oxygen and slag (sample Y1) of each heat, the [Mg], [Al], [Si], $[\mathrm{Ca}],[\mathrm{O}]$ soluble in the steel were calculated ${ }^{31,32}$. The FTmisc, FToxid and FactPS databases were used for the equilibrium calculation. Steel-Refractory and Steel-Slag reactions in all cases were considered by specific calculation of [Mg]. Afterwards, the construction of the stability diagram of $\mathrm{MgO} / \mathrm{MgO} \cdot \mathrm{Al}_{2} \mathrm{O}_{3} / \mathrm{Al}_{2} \mathrm{O}_{3}$ oxide inclusions was calculated from the Phase Diagram module, with Fe-Al-Mg-O considered as components of the system ${ }^{16,18-23,33-35}$. The temperature was set at $1600^{\circ} \mathrm{C}$ and $1 \mathrm{~atm}$ pressure and the standard state of the oxides was considered as pure oxides. Simultaneously, the iso-oxygen content lines are also calculated for the different oxygen contents. Subsequently, all simulated results were overlaid using the Figure module. Through thermodynamic calculations, the amount of [Ca] required for the disappearance of spinel inclusion was established from the results of the iterations in which the spinel phase disappears.

\section{Results and Discussion}

Table 1 summarizes the results of chemical analyses for the slag and steel and thermodynamic calculations of the steelmaking process in the analyzed heats. The results in this table will be explained in the course of the discussion of the results. For a better analysis of the results, the data obtained from the heats were separated into two sequence groups (A and B) to find out their effect on the variable of interest in the process and formation of inclusions in steel. 


\subsection{Effects of the slag chemical composition on $\mathrm{MgO}$ content of inclusions}

Figure 2 shows the different compositions of the industrial slags of the analyzed heats represented in the pseudo-ternary system $\mathrm{CaO}-\mathrm{SiO}_{2}-\mathrm{Al}_{2} \mathrm{O}_{3}-11 \% \mathrm{MgO}$ at the temperature of $1550^{\circ} \mathrm{C}$.

As shown in Figure 2 all slag compositions are located in a $\mathrm{MgO}$ saturated region, $(\mathrm{MgO}+\mathrm{slag}$ liquid), with $\mathrm{MgO}$ saturation values (Table 1), ranging from 3.6 to 6 mass $\%$. As can be seen in Table 1, the $\mathrm{Al}_{2} \mathrm{O}_{3}, \mathrm{CaO}, \mathrm{SiO}_{2}$ contents of these slags range between $15-25 \%, 47-52 \%$ and $13-17.6 \%$ by mass, respectively. Typical slag compositions for secondary refining of high basicity (2.8-3.6), saturated in $\mathrm{CaO}$ and $\mathrm{MgO}$ and with high content of alumina ${ }^{25,36,37}$. $\mathrm{MgO}$ content in the slag is in the range of 9 to 16 mass $\%$. Values of 75 to $100 \%$ of the liquid fraction were observed. With the exception of heats with $100 \%$ liquid fraction, the solid slag fraction ranges from $7 \%$ to $25 \%$ due to the precipitation of saturated phases $\left(\mathrm{C}_{2} \mathrm{~S}\right.$ and $\left.\mathrm{MgO}\right)$.

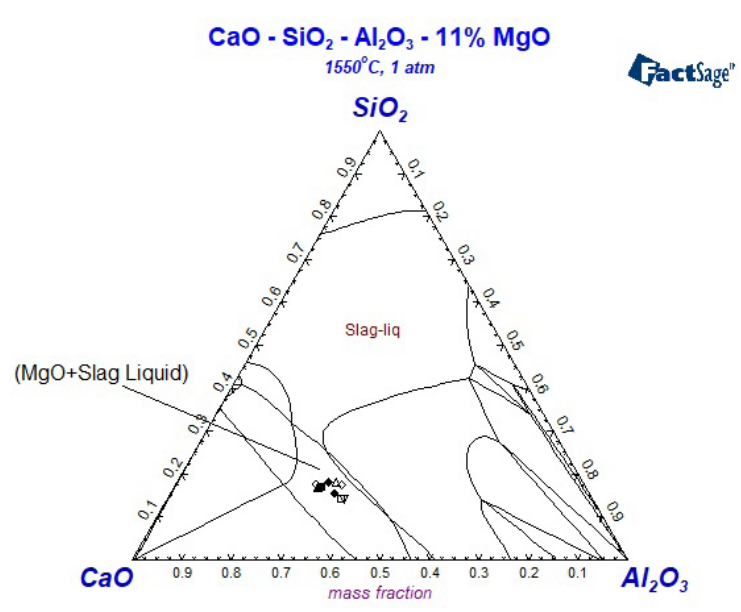

Figure 2. Measured data of refining slags from different industrial heats. Temperature: $1550^{\circ} \mathrm{C}$.

Table 1. Summary of the main slag and steel parameters measured and calculated of the analyzed samples.

\begin{tabular}{|c|c|c|c|c|c|c|c|c|c|c|}
\hline & \multirow{4}{*}{ Parameters } & \multicolumn{9}{|c|}{ Heats } \\
\hline & & A1 & A2 & A3 & A4 & A5 & $\mathrm{B} 1$ & $\mathrm{~B} 2$ & B3 & B4 \\
\hline & & \multicolumn{9}{|c|}{ Sequence } \\
\hline & & 1 & 2 & 3 & 4 & 5 & 2 & 3 & 4 & 5 \\
\hline \multirow{12}{*}{$\begin{array}{l}\text { Slag } \\
\text { Y1 }\end{array}$} & $\mathrm{FeO}$ (wt.\%) & 0.63 & 0.68 & 1.14 & 0.55 & 0.69 & 0.38 & 0.44 & 0.5 & 0.43 \\
\hline & $\mathrm{FeO}+\mathrm{MnO}$ (wt.\%) & 0.85 & 0.77 & 1.27 & 0.64 & 0.80 & 0.46 & 0.51 & 0.58 & 0.52 \\
\hline & $\mathrm{CaO}$ (wt.\%) & 52.02 & 49.10 & 48.31 & 48.86 & 47.25 & 50.11 & 52.09 & 52.57 & 49.99 \\
\hline & $\mathrm{Al}_{2} \mathrm{O}_{3}$ (wt.\%) & 18.23 & 23.40 & 15.43 & 24.95 & 19.47 & 22.78 & 17.96 & 17.03 & 19.77 \\
\hline & $\mathrm{SiO}_{2}$ (wt.\%) & 16.83 & 13.56 & 17.08 & 14.04 & 16.84 & 14.98 & 16.40 & 16.10 & 17.57 \\
\hline & $\mathrm{MgO}$ (wt.\%) & 9.24 & 10.77 & 15.79 & 9.87 & 13.13 & 9.48 & 11.07 & 11.22 & 10.07 \\
\hline & $\mathrm{CaO} / \mathrm{SiO}_{2}$ & 3.10 & 3.60 & 2.83 & 3.50 & 2.80 & 3.35 & 3.18 & 3.27 & 2.85 \\
\hline & (S) (wt.\%) & 1.23 & 1.49 & 0.82 & 1.12 & 0.95 & 1.31 & 1.17 & 1.12 & 1.35 \\
\hline & Solid portion* (wt.\%) & 11.6 & 0 & 25.2 & 0 & 7.3 & 0 & 13.3 & 17.4 & 6.8 \\
\hline & Liquid portion* (wt.\%) & 88.4 & 100 & 74.8 & 100 & 92.7 & 100 & 86.7 & 82.6 & 93.2 \\
\hline & Saturation $\mathrm{MgO}^{*}$ (wt.\%) & 4.14 & 5.16 & 3.62 & 6.00 & 5.62 & 5.51 & 4.03 & 3.93 & 5.56 \\
\hline & $\mathrm{C}($ wt. \%) & 0.983 & 1.02 & 1.01 & 0.974 & 0.974 & 0.956 & 0.995 & 0.932 & 0.965 \\
\hline \multirow{7}{*}{$\begin{array}{l}\text { Steel } \\
\mathrm{X} 1\end{array}$} & Si (wt.\%) & 0.29 & 0.26 & 0.24 & 0.24 & 0.22 & 0.23 & 0.26 & 0.22 & 0.25 \\
\hline & $\mathrm{Al}$ (wt.\%) & 0.006 & 0.005 & 0.003 & 0.003 & 0.003 & 0.004 & 0.004 & 0.004 & 0.004 \\
\hline & $\mathrm{Ca}($ wt. $\%)$ & 0.0004 & 0.0007 & 0.0010 & 0.0002 & 0.0005 & 0.0002 & 0.0005 & 0.0005 & 0.0005 \\
\hline & S (wt.\%) & 0.002 & 0.004 & 0.008 & 0.002 & 0.003 & 0.004 & 0.005 & 0.002 & 0.003 \\
\hline & Mn (wt.\%) & 0.312 & 0.301 & 0.292 & 0.349 & 0.326 & 0.33 & 0.313 & 0.295 & 0.301 \\
\hline & $\mathrm{Cr}(\mathrm{wt} . \%)$ & 1.371 & 1.386 & 1.381 & 1.391 & 1.386 & 1.359 & 1.367 & 1.389 & 1.389 \\
\hline & Total oxygen-TO (ppm) & 18 & 14 & 8 & 12 & 15 & 16 & 16.5 & 19 & 11 \\
\hline \multirow{13}{*}{$\begin{array}{l}\text { Steel } \\
\text { X2 }\end{array}$} & & & & & & & & & & \\
\hline & $\mathrm{C}(\mathrm{wt} . \%)$ & 1.01 & 1.03 & 1.04 & 1.01 & 1.01 & 0.97 & 0.98 & 0.99 & 0.98 \\
\hline & Si (wt.\%) & 0.29 & 0.26 & 0.24 & 0.25 & 0.22 & 0.23 & 0.25 & 0.24 & 0.24 \\
\hline & $\mathrm{Al}($ wt. $\%)$ & 0.004 & 0.003 & 0.002 & 0.003 & 0.002 & 0.003 & 0.002 & 0.003 & 0.002 \\
\hline & $\mathrm{Ca}(w \mathrm{t} . \%)$ & 0.0002 & 0.0001 & 0.0003 & 0.0002 & 0.0003 & 0.0001 & 0.0003 & 0.0003 & 0.0003 \\
\hline & S (wt.\%) & 0.009 & 0.008 & 0.013 & 0.008 & 0.007 & 0.006 & 0.01 & 0.008 & 0.01 \\
\hline & Mn (wt.\%) & 0.31 & 0.30 & 0.29 & 0.34 & 0.33 & 0.34 & 0.32 & 0.31 & 0.30 \\
\hline & $\mathrm{Cr}(\mathrm{wt} . \%)$ & 1.39 & 1.38 & 1.38 & 1.4 & 1.39 & 1.37 & 1.38 & 1.4 & 1.39 \\
\hline & Total oxygen-TO (ppm) & 22 & 22 & 13 & 10 & 12 & 17 & 13,5 & 18 & 29 \\
\hline & {$[\mathrm{Al}] *(\mathrm{ppm})$} & 130.480 & 128.207 & 102.211 & 117.995 & 89.409 & 111.178 & 118.677 & 125.497 & 94.789 \\
\hline & {$[\mathrm{Ca}] *(\mathrm{ppm})$} & 0.009 & 0.006 & 0.006 & 0.005 & 0.004 & 0.005 & 0.009 & 0.013 & 0.004 \\
\hline & {$[\mathrm{O}] *(\mathrm{ppm})$} & 0.471 & 0.557 & 0.602 & 0.648 & 0.763 & 0.617 & 0.480 & 0.400 & 0.712 \\
\hline & {$[\mathrm{Mg}] *(\mathrm{ppm})$} & 1.281 & 1.079 & 0.994 & 0.924 & 0.779 & 0.962 & 1.241 & 1.487 & 0.836 \\
\hline
\end{tabular}


(a)

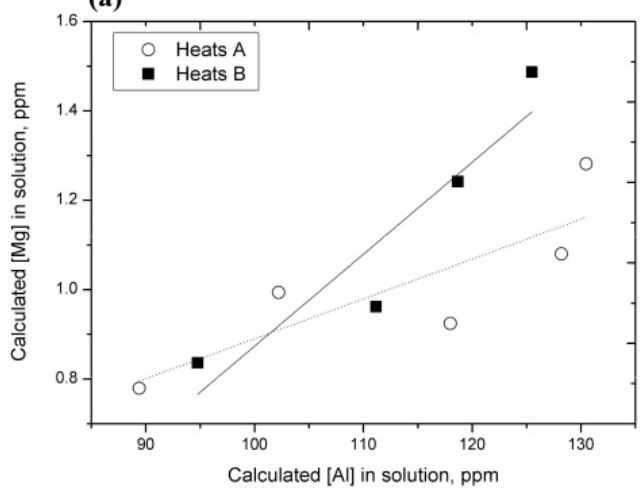

(b)

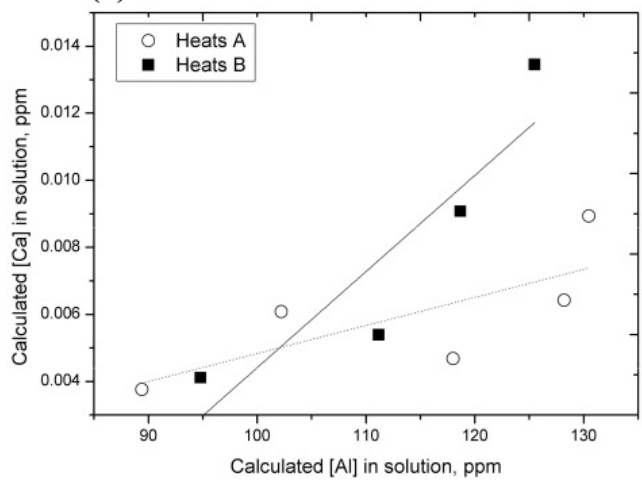

Figure 3. Relation between the contents of a) $[\mathrm{Mg}]$, b) $[\mathrm{Ca}]$ and $[\mathrm{Al}]$ dissolved in the steel of the studied heats. Results calculated by FactSageTM 7.2.
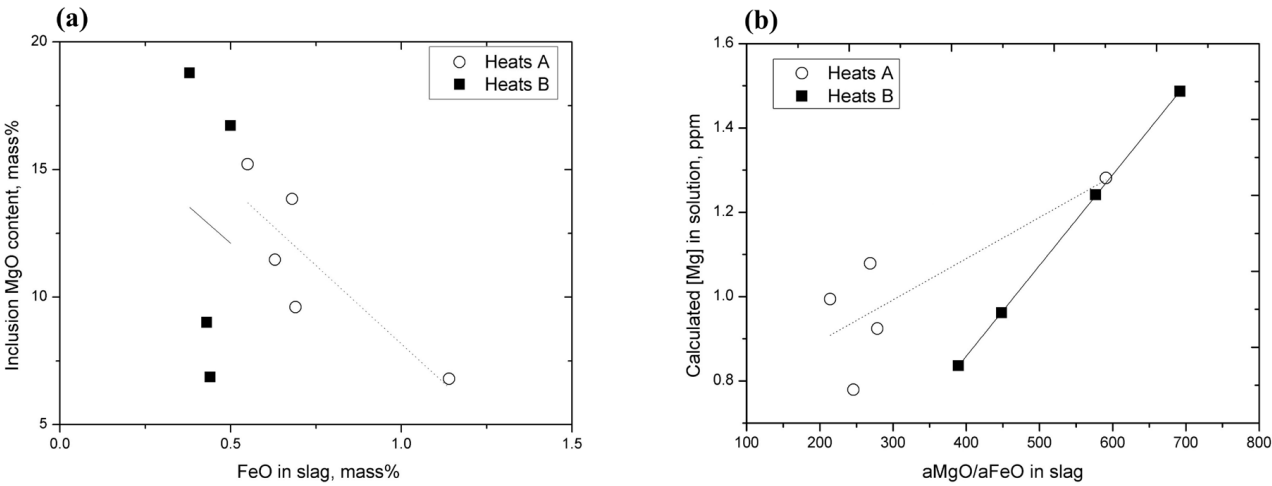

Figure 4. Influence of a) the $\mathrm{FeO}$ content in the slag on the $\mathrm{MgO}$ content in the inclusions (measured results) and b) the activity ratio $\mathrm{aMgO} / \mathrm{aFeO}$ on the $[\mathrm{Mg}]$ dissolved in the steel (results calculated by FactSageTM 7.2.).

Figure 3 shows the calculated values of $[\mathrm{Mg}]$ and $[\mathrm{Ca}]$ dissolved in the steel as a function of the content of [Al] in solution.

As can be seen, the content of $[\mathrm{Mg}]$ and $[\mathrm{Ca}]$ increases in the steel with the increase of dissolved aluminum. This supports the theory of the reduction of $\mathrm{MgO}$ and $\mathrm{CaO}$ in the slag by the aluminum dissolved in the steel which corresponds to the slag-metal reactions described in Equations 1 and $2^{24,38,39}$. With the increase of $[\mathrm{Mg}]$ and $[\mathrm{Ca}]$ in steel, the steel-inclusion interaction should occur. First, transforming the inclusion of $\mathrm{Al}_{2} \mathrm{O}_{3}$ into $\mathrm{MgO} \cdot \mathrm{Al}_{2} \mathrm{O}_{3}$ spinel by increasing $\mathrm{MgO}$ in the inclusions. Subsequently, the transformation of $\mathrm{MgO} \cdot \mathrm{Al}_{2} \mathrm{O}_{3}$ to complex inclusions $\mathrm{CaO}-\mathrm{MgO}-\mathrm{Al}_{2} \mathrm{O}_{3}$ occurs by increasing the calcium content in the inclusions.

$$
\begin{aligned}
& 3(\mathrm{MgO}) \text { slag }+2[\mathrm{Al}]=\left(\mathrm{Al}_{2} \mathrm{O}_{3}\right) \text { slag }+3[\mathrm{Mg}] \\
& 3(\mathrm{CaO}) \text { slag }+2[\mathrm{Al}]=\left(\mathrm{Al}_{2} \mathrm{O}_{3}\right) \text { slag }+3[\mathrm{Ca}]
\end{aligned}
$$

In the present work, [Al] contents range (calculated) in the steel varied between $0.0089-0.0130$ mass $\%$ ( $89-130 \mathrm{ppm}$ ) and are considered minimum levels to those found in the literature ${ }^{4,37,40,41}$.

Figure 4a-b shows the relationship between the $\mathrm{FeO}$ content in the slag and the $\mathrm{MgO}$ content in the inclusions and the activity ratio $\mathrm{aMgO} / \mathrm{aFeO}$ in liquid slag on the $[\mathrm{Mg}]$ dissolved in the steel.
From Figure $4 \mathrm{a}$ it is observed that with the decrease of the amount of $\mathrm{FeO}$ in the slag the content of $\mathrm{MgO}$ in the inclusions tends to be greater. That is, deoxidized slags promote the reduction of $\mathrm{MgO}$ in the slag by increasing the $[\mathrm{Mg}]$ dissolved in the steel. According to results of other researchers ${ }^{38,39}$ slags with low reductive oxides (such as $\% \mathrm{FeO}$ and $\% \mathrm{MnO}$ ) may promote inclusions with higher $\mathrm{MgO}$ content. Although not shown in this study, the relationship between $\mathrm{MgO}$ in the inclusions considering the contents of $(\% \mathrm{FeO}+\% \mathrm{MnO})$ in the slag did not promote significant changes in the tendency of the results presented only with $\mathrm{FeO}$. The average $\mathrm{MnO}$ contents in the slags were (Heats A: $0.128 \%$, Heats B: $0.085 \%$ ).

Figure $4 \mathrm{~b}$ shows a good correlation between the dissolved $[\mathrm{Mg}]$ content and the $\mathrm{aMgO} / \mathrm{aFeO}$ ratio at the end of the process. According to Mendez et al. ${ }^{38}$, the effect of the composition of the slag appears in the ratio between $\mathrm{FeO}$ and $\mathrm{MgO}$ activity and the activity of $[\mathrm{Mg}]$ in liquid steel, $[\mathrm{Mg}]=\mathrm{aMgO} / \mathrm{aFeO}$. From this equation, it is clear that as the $\mathrm{FeO}$ activity decreases, the oxygen activity dissolved at the interface is reduced, thus promoting $[\mathrm{Mg}]$ diffusion to the steel by modifying the composition of $\mathrm{Al}_{2} \mathrm{O}_{3}$ inclusions.

Figure 5a-b shows the influence of binary basicity $\left(\% \mathrm{CaO} / \% \mathrm{SiO}_{2}\right)$ on the $\mathrm{MgO}$ content in the inclusions of the heats analyzed. 
(a)

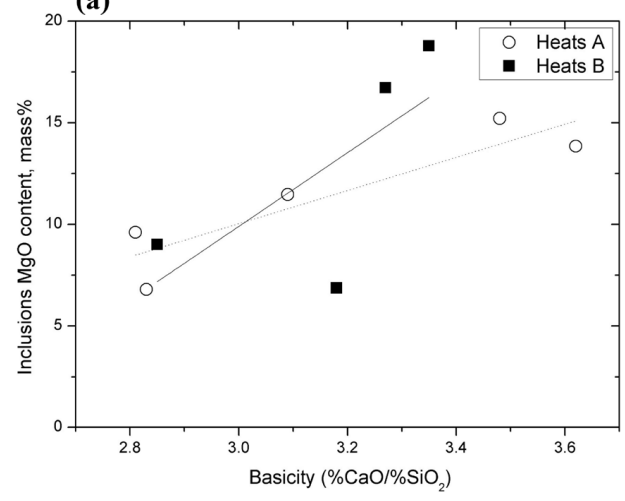

(b)

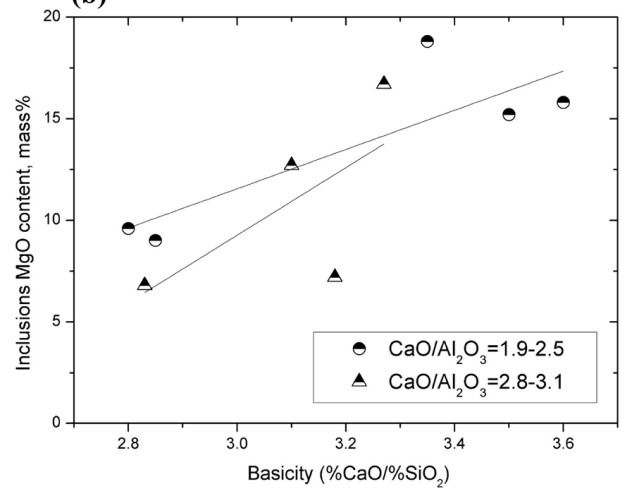

Figure 5. Influence of basicity on $\mathrm{MgO}$ content in inclusions according to a) heat groups $\mathrm{A}$ and $\mathrm{B}$, and $\mathrm{b}$ ) to the $\% \mathrm{CaO} / \% \mathrm{Al}_{2} \mathrm{O}{ }_{3}$ ratio. Measured results.

Figure 5a is classified according to heat groups A and B and Figure $5 \mathrm{~b}$ is grouped independently of heat groups $\mathrm{A}$ and $\mathrm{B}$, but according to the $\% \mathrm{CaO} / \% \mathrm{Al}_{2} \mathrm{O}_{3}$ ratio. As can be observed from the figures, in addition to the reasonable value of the correlation coefficient of the data, in both the $\mathrm{MgO}$ in the inclusions increases with the increase of the basicity. These results are similar to those obtained by Deng et al. ${ }^{11}$, Okuyama et al. ${ }^{15}$, Takayuki and $\mathrm{Kaoru}^{42}$ and Tang and $\mathrm{Li}^{43}$, who verified that the maximum $\mathrm{MgO}$ content in the inclusions was affected by the increase of binary basicity in the slag.

Okuyama et al. ${ }^{15}$ investigated the influence of the slag composition on the formation of spinel inclusions $\left(\mathrm{MgAl}_{2} \mathrm{O}_{4}\right)$ and concluded that by reducing the basicity $\left(\% \mathrm{CaO} / \% \mathrm{SiO}_{2}\right)$ and $\left(\% \mathrm{CaO} / \% \mathrm{Al}_{2} \mathrm{O}_{3}\right)$ ratio in the slag, the $\mathrm{MgO}$ content in alumina inclusions would be reduced. Deng et al. ${ }^{11}$ reported that with the binary basicity at levels around 3 to 4 , together with a slag with $20 \mathrm{wt} \%$ in $\mathrm{Al}_{2} \mathrm{O}_{3}$, the alumina activity decreases while that from $\mathrm{MgO}$ increases in the slag. This means that the dissolution of $\mathrm{Mg}$ into the steel bath is difficult, being favorable for the control of spinel formation.

Figure 6 shows the different ranges of $\mathrm{SiO}_{2}$ contents in the slag for the analyzed heats.

The values of the data, which vary in the range of 13.6 to 17.6 mass $\%$, show the tendency of reduction in the $\mathrm{MgO}$ inclusion content with the increase of the $\mathrm{SiO}_{2}$ content in the slag. This fact is in accordance with experimental results presented by Park and Todoroki ${ }^{16}$, Todoroki and Mizuno ${ }^{44}$, Jiang et al..$^{23,33}$, Tang ${ }^{39}$ and those calculated results by Shin et al ${ }^{45}$. This behavior is explained according to Equations 3, 4 and 5 .

$$
\begin{aligned}
& \left(\mathrm{SiO}_{2}\right)_{\text {slag }}+2[\mathrm{Mg}]=2(\mathrm{MgO})_{\text {slag }}+[\mathrm{Si}] \\
& \left(\mathrm{SiO}_{2}\right)_{\text {slag }}+2[\mathrm{Ca}]=2(\mathrm{CaO})_{\text {slag }}+[\mathrm{Si}] \\
& 3\left(\mathrm{SiO}_{2}\right)_{\text {slag }}+4[\mathrm{Al}]=2\left(\mathrm{Al}_{2} \mathrm{O}_{3}\right)_{\text {slag }}+3[\mathrm{Si}]
\end{aligned}
$$

All of the aforementioned authors consider that lower contents of $[\mathrm{Mg}]$ and $[\mathrm{Ca}]$ dissolved in the steel bath are expected as the content of $\mathrm{SiO}_{2}$ in the slag increases. This prevents the pickup of $[\mathrm{Mg}]$ and $[\mathrm{Ca}]$, not allowing the transformation of the spinel inclusions in the $\mathrm{MgO}$ inclusions or for inclusions in the $\mathrm{CaO}-\mathrm{Al}_{2} \mathrm{O}_{3}-\mathrm{MgO}-\mathrm{SiO}_{2}$ system. In addition, $\mathrm{SiO}_{2}$ can further stabilize the spinel formed. In this

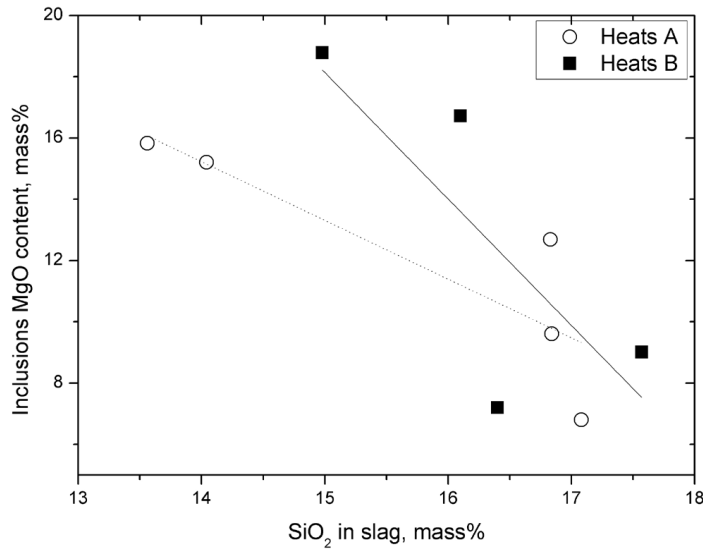

Figure 6. Influence of $\mathrm{SiO}_{2}$ contents in slag on $\mathrm{MgO}$ content in inclusions.

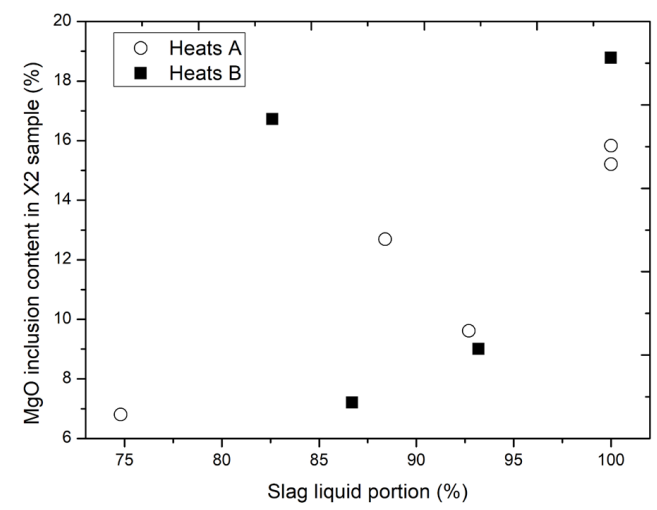

Figure 7. Relationship between the $\mathrm{MgO}$ content in the inclusions and fraction mass percentage of the liquid phase in slag.

work the lower $\mathrm{MgO}$ contents will be obtained with contents between $16-17 \% \mathrm{SiO}_{2}$ in the slag. Still of the thermodynamic results it can be observed that with the $\mathrm{SiO}_{2}$ increase the $\mathrm{CaO}$ content increases and the $\mathrm{Al}_{2} \mathrm{O}_{3}$ content reduces until it remains constant from $16 \%$. 
It is important to consider that the basicity of the slag is reduced with increasing silica (acid slag). The implications of this will be: aluminum as the most active deoxidation agent can reduce silica from a slag that increases these element contents in a metal; the bigger silica content in a slag, the bigger will be the losses of aluminum in the metal phase, forming alumina inclusions.

Figure 7 shows the relationship between the $\mathrm{MgO}$ content in the inclusions and the liquid fraction in the slag of the analyzed heats.

As shown in Figure 7, there is an increase in the $\mathrm{MgO}$ content in the inclusions with increasing liquid fraction in the slag. This suggests that the slag/steel interaction is favored when the slag is more liquid and consequently increasing the transfer of $\mathrm{Mg}$ from the slag to the bath and subsequently to the inclusions. Similar results were obtained by Bartosiaki et al. ${ }^{25}$ and Pereira et al. ${ }^{29}$.

According to Bartosiaki ${ }^{25}$, alumina acts as a flux in basic slags and high alumina contents are used to promote an abundant liquid phase without compromising the removal and absorption of nonmetallic inclusions. On the other hand, the binary basicity of the slag must be high enough to ensure the indirect treatment of the inclusions with calcium.

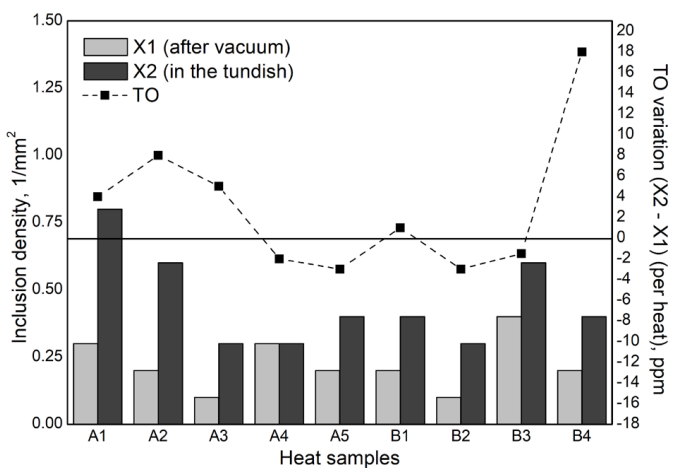

Figure 8. Comparison between the inclusion density and the total oxygen variations content in samples X1 (after vacuum) and X2 (in the tundish).

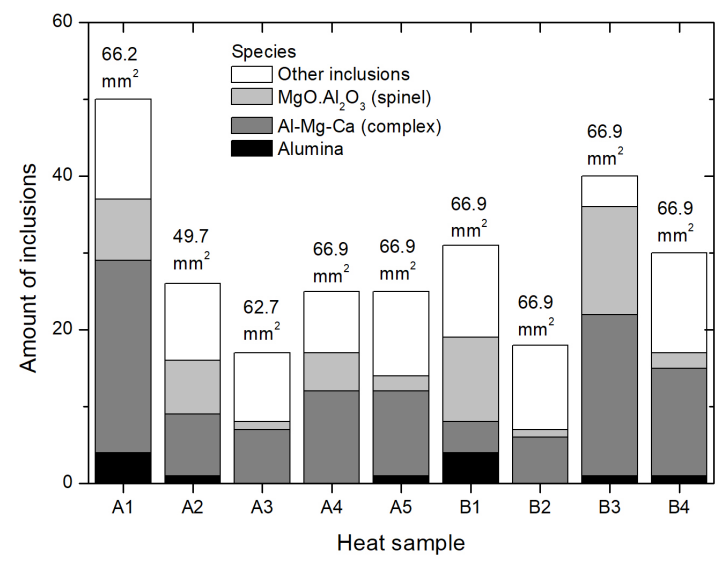

Figure 9. Amount and species of inclusions detected in the tundish Sample X2.

\subsection{Inclusion characterization}

The total oxygen (TO) content, composed in the sum of the oxygen dissolved in the steel and the oxygen present in the oxides (inclusions), can be used as a cleaning parameter in steels ${ }^{46}$. Figure 8 shows a comparison between the inclusion density and the total oxygen content in samples X1 (after vacuum) and X2 (in the tundish).

As can be observed after vacuum and in the tundish there is an increase in the density of inclusions for the analyzed heats. In parallel, the same tendency was found for the total oxygen (TO) variations between samples X1 and X2. In Figure 8, each sample presents, in particular, its total oxygen variation. However, there is a relationship between increasing the density of inclusions with the TO content. The positive variations of TO indicate reoxidation of the liquid steel (there was an increase in the total oxygen content). In the case of negative variations, most of them are close to 0 (without variation), according to samples A4, A5, B1 and B2, but it does not mean that there has not been a severe reoxidation as in the others. This behavior in the increase of the inclusions densities and total oxygen may suggests that reoxidation events occurred in many of these heats. In this case, re-oxidation is merely one of the possibilities for increasing the density of inclusions in steel.

It is known from literature that after secondary refining and during casting, liquid steel can be exposed to uncontrolled sources of oxygen (air). Materials listed among the sources include, the refractory material and oxygen passage through the slag from the tundish, re-oxidation of the steel during transfer between the ladle and tundish and especially during the ladle pouring to the tundish during the start of heats and after changing ladles ${ }^{47,48-50}$. According to Shu-feng et al. ${ }^{51}$, any increase in oxygen potential since re-oxidation may lead to the formation of secondary spinel inclusions. On the other hand, according to Park and Todoroki ${ }^{16}$ and Yanyan et al. ${ }^{52}$, during the steelmaking process the steel presents a temperature drop promoting the formation of new inclusions of alumina and/or spinel and, in the meantime, increasing the non-metallic inclusion densities.

The typical maximum cleaning requirements specified for bearing steels correspond to a total oxygen value (TO) $<10 \mathrm{ppm}$. However, as observed in this study, it was very difficult to control TO at these levels, even reporting TO very high up to 22 and $29 \mathrm{ppm}$ in some of the heats. Howewer, to obtain low oxygen in steel, high basicity refining slag with lower $\mathrm{Fe}_{\mathrm{t}} \mathrm{O}$ content and low $\mathrm{C} / \mathrm{A}$ ratio ranges during ladle furnace refining is necessary. There are new technologies to prevent oxygen contamination of molten steel: the prevention of slag invasion into the tundish by controlling the amount of molten steel remaining in the ladle; the prevention of air contamination of molten steel flow from ladle to tundish by adopting the tundish seal box or use of protective shrouding to protect from re-oxidation; the prevention of air contamination of molten steel by a perfect seal between the tundish and immersion nozzles and the prevention of the involution of mold powder by the control of immersion depth of immersion nozzles ${ }^{8,36,37}$.

Figure 9 illustrates the variation of relative fraction (population) in the quantitative analyis of each type of inclusion in molten steel at $1550^{\circ} \mathrm{C}$ in the tundish. It can be 
observed that almost all the samples presented similar species of inclusions groups including, other inclusions (calcium alumino-silicate, sulfides and others), spinels, complex and alumina, the last three being those not completely transformed into calcium aluminates liquid. Alumina inclusions are present in samples A1, A2, A5, B1, B3 and B4. In regards to particle counting, it is important to identify samples A3 and B2 as the samples with the lowest indices, appearing with less than 20 particles detected.

The observed inclusions for the complex as well as the partially modified inclusions have an average maximum size of $5.96 \mu \mathrm{m}$ with most of the bands of diameters above $35 \%$ as opposed to diameters of 4.19 and $5.21 \mu \mathrm{m}$ that were below this ratio. Regarding the inclusions of pure spinel with a average maximum size of $8.05 \mu \mathrm{m}$, a maximum proportion to $35 \%$ in the average diameter ranges of 3.77 and $4.79 \mu \mathrm{m}$ is observed, and below of $22 \%$ for the rest of the inclusion diameters. In geral, the proportion of spinel inclusions observed in these heats are in low proportion to the amount of complex inclusions.

Table 2 shows the average compositions of all inclusions taken from the distributor (sample $\mathrm{X} 2$ ), together with the $\mathrm{CaO} / \mathrm{Al}_{2} \mathrm{O}_{3}(\mathrm{C} / \mathrm{A})$ ratios in the inclusion.

According to Bao et al. ${ }^{41}$, with the aim of modifying the solid inclusions into liquids $\left(\mathrm{C}_{12} \mathrm{~A}_{7}\right)$, the $\mathrm{CaO} / \mathrm{Al}_{2} \mathrm{O}_{3}$ ratio of the inclusions should be approximately 0.86 and the $\mathrm{MgO}$ content should be controlled below $10 \%$.

Based on these results, in the case of heats $\mathrm{A}$, heats $\mathrm{A} 3$ and $\mathrm{A} 2$ show a high $\mathrm{C} / \mathrm{A}$ ratio of inclusions, which means that they were quite modified compared to heats $\mathrm{A} 1$, $\mathrm{A} 4$ and $\mathrm{A} 5$. For these heats $\mathrm{A}$, the $\mathrm{MgO}$ content is high in heats A1, A2 and A4 with values of 11.47, 13.86, 15.21 and, for heats A3 and A5 with values of 6.8 and 9.61. As can be seen, heat $\mathrm{A} 2$ has a C/A ratio of 0.8 with a high final average $\mathrm{MgO}$ content in the inclusions, in which case a partial modification of the inclusions may be considered. On the other hand, for heats $\mathrm{B}$, only heats $\mathrm{B} 2$ and $\mathrm{B} 4$ reach the maximum modification of the inclusions with $\mathrm{C} / \mathrm{A}$ values of 0.80 and 0.84 , unlike heats $\mathrm{B} 1$ and $\mathrm{B} 3$ both with a value of 0.46 , also showing that their modification was insufficient. The high $\mathrm{MgO}$ content is in the heats B1 and B3, with 18.78 and 16.72 as opposed to the B2 and B4 heats with values of 6.87 and 9.01 (and close to those of heats A3 and A5).

According to the studies of other researchers ${ }^{34,39,49,50,53}$, this behavior is associated with the transformation mechanism of inclusion following the sequence $\mathrm{Al}_{2} \mathrm{O}_{3} \rightarrow \mathrm{MgO} \cdot \mathrm{Al}_{2} \mathrm{O}_{3} \rightarrow \mathrm{CaO}-\mathrm{MgO}-\mathrm{Al}_{2} \mathrm{O}_{3}$. That is, the transformation of the inclusions takes place first from $\mathrm{Al}_{2} \mathrm{O}_{3}$ to $\mathrm{MgO} \cdot \mathrm{Al}_{2} \mathrm{O}_{3}$, followed by transformation of $\mathrm{MgO} \cdot \mathrm{Al}_{2} \mathrm{O}_{3}$ into $\mathrm{CaO}-\mathrm{MgO}-\mathrm{Al}_{2} \mathrm{O}_{3}$. In this last transformation, the $\mathrm{CaO}$ ratio increases and reduces the proportion of $\mathrm{MgO}$ in the inclusions because of the reduction of $\mathrm{MgO}$ in the inclusions by [Ca] in the steel. According to Verma et al. ${ }^{54}$, after modification with calcium, the $[\mathrm{Mg}]$ should return to the liquid steel. This [Mg] should reform spinel inclusions during re-oxidation.

The low C/A ratio in the inclusions shows itself as one of the reasons why spinel inclusions are frequently observed in these heats ${ }^{51}$. An estimation of the Ca contents required for the spinel modification was performed using thermodynamic calculations, Table 3, through the variation of the Ca content in the samples collected at the distributor (X2). Comparing the total $\mathrm{Ca}$ contents, the amount of calcium required is high for heats A1, A2, B1 and B3 and to a lesser extent for heats $\mathrm{A} 4$ and $\mathrm{B} 2$ and nonexistent for heats $\mathrm{A} 3, \mathrm{~A} 5$ and $\mathrm{B} 4$.

Some of these heats, such as the sequential heats, A1 (1st), A2 (2nd), B1 (2nd), B3 (4th) required more calcium to be added. There were almost constant additions to the heats A3, A4, A5, B2 and B4. According to Geldenhuis and Pistorius $^{55}$ the amount of calcium to be added depends on the concentration of alumina inclusions in the steel. Recently, Kumar and Pistorius ${ }^{56-58}$ emphasizes the low rate of transfer of calcium by slag to the inclusions. On the other hand, Yang Wen et al. ${ }^{34}$ considered re-oxidation of molten steel and precipitation of $\mathrm{CaS}$ as factors for consuming large amounts of calcium that was expected to be used to modify inclusions to calcium aluminates with low melting points. According Costa e Silva ${ }^{1}$ the amount of calcium needed to modify oxides depends on the total oxygen content in the steel. To date, there is no method of determining total oxygen in time to use it for a decision on the amount of calcium to

Table 2. Average inclusion composition (samples X2) in tundish (mass\%).

\begin{tabular}{crrrrrrr}
\hline Heats & $\mathrm{MgO}$ & $\mathrm{Al}_{2} \mathrm{O}_{3}$ & $\mathrm{SiO}_{2}$ & $\mathrm{CaO}$ & $\mathrm{C} / \mathrm{A}$ inclusion & $\mathrm{S}$ & $\mathrm{MnO}$ \\
\hline $\mathrm{A} 1$ & 11.47 & 49.65 & 21.34 & 19.35 & 0.39 & 2.69 & 4.15 \\
\hline $\mathrm{A} 2$ & 13.86 & 35.72 & 21.88 & 28.61 & 0.80 & 4.08 & 10.48 \\
\hline $\mathrm{A} 3$ & 6.80 & 40.54 & 17.82 & 35.65 & 0.88 & 2.03 & 1.77 \\
\hline $\mathrm{A} 4$ & 15.21 & 43.05 & 14.86 & 30.46 & 0.71 & 2.63 & 2.64 \\
\hline $\mathrm{A} 5$ & 9.61 & 45.60 & 15.24 & 33.94 & 0.74 & 1.93 & 2.26 \\
\hline $\mathrm{B} 1$ & 18.78 & 49.98 & 16.27 & 22.89 & 0.46 & 1.99 & 7.41 \\
\hline $\mathrm{B} 2$ & 6.87 & 35.10 & 27.07 & 28.04 & 0.80 & 2.58 & 4.73 \\
\hline $\mathrm{B} 3$ & 16.72 & 51.42 & 11.49 & 23.63 & 0.46 & 2.59 & 2.02 \\
\hline $\mathrm{B} 4$ & 9.01 & 37.12 & 20.41 & 31.26 & 0.84 & 2.65 & 3.08 \\
\hline
\end{tabular}

Table 3. Total Calcium content in steel and [Ca] calculated for the disappearance of spinel inclusions. Sample X2.

\begin{tabular}{lccccccccc}
\hline \multicolumn{1}{c}{ Heats } & A1 & A2 & A3 & A4 & A5 & B1 & B2 & B3 & B4 \\
\hline Total Ca $(\mathrm{ppm})$ & 2 & 1 & 3 & 2 & 3 & 1 & 3 & 3 & 3 \\
\hline Spinel vanish, $[\mathrm{Ca}](\mathrm{ppm})$ & 8 & 7 & 3 & 3 & 3 & 5 & 4 & 7 & 3 \\
\hline
\end{tabular}


be added. The use of thermodynamics to define castability windows (liquid inclusions) would be the most appropriate method for optimization. This methodology has been used by Bielefeldt W. and Vilela A.C.F.; Lino et al. with great success $^{59,60}$.

Figure 10 shows the calculated stability diagram used to study the formation of $\mathrm{MgO} / \mathrm{MgO} \cdot \mathrm{Al}_{2} \mathrm{O}_{3} / \mathrm{Al}_{2} \mathrm{O}_{3}$ oxide inclusions in the liquid steel with the corresponding calculated $[\mathrm{Mg}]$ and $[\mathrm{Al}]$ values of the analyzed heats.

As can be seen, all the levels of $[\mathrm{Mg}]$ and $[\mathrm{Al}]$ dissolved in the steel of the other heats are in the stable spinel formation region $\left(\mathrm{MgO} \cdot \mathrm{Al}_{2} \mathrm{O}_{3}\right)$, which may explain the appearance of these inclusions in the steel. However, one can choose one of the following countermeasures from the stability diagrams; first, for a range of 89-130 ppm Al dissolved in the steel, the stability of the spinel will decrease significantly with increasing $\mathrm{Mg}$ content in the steel greater than about 0.001 mass $\%$ (10ppm). Second, and as previously shown in Table 3, add of several ppm $\mathrm{Ca}$ for the formation of liquid inclusions rather than spinel.

Figure 11 shows a comparison of the inclusion composition distribuition of different sizes between two typical heats $\mathrm{A} 3$ and $\mathrm{B} 3$ in the ternary diagrams $\mathrm{CaO}-\mathrm{SiO}_{2}-\mathrm{Al}_{2} \mathrm{O}_{3}$ (sample X1-after vacuum) and $\mathrm{CaO}-\mathrm{Al}_{2} \mathrm{O}_{3}-\mathrm{MgO}$ (sample X2-tundish) system.
Two conditions were selected that illustrate the two groups of inclusions. These conditions represent the best and worst scenario, considering steps X1 and X2 (Figure 11). For the A3 heat, inclusions of $\mathrm{CaO}$ and alumina, as well as larger inclusions of silicates, are observed after vacuum. Subsequently in the tundish, most of the inclusions were concentrated in the liquid region (region of low melting point). However for

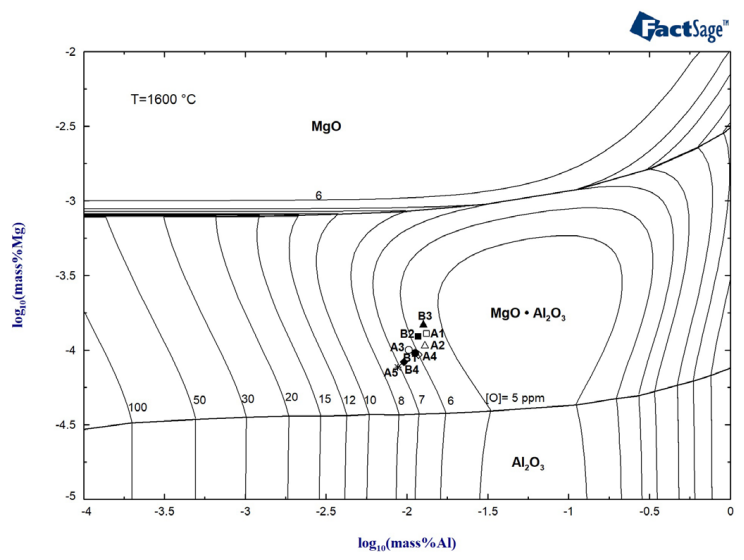

Figure 10. Stability diagram for $\mathrm{MgO} / \mathrm{MgO} \cdot \mathrm{Al}_{2} \mathrm{O}_{3} / \mathrm{Al}_{2} \mathrm{O}_{3}$ inclusions at $1600^{\circ} \mathrm{C}(1873 \mathrm{~K})$ for the analized heats. Calculated by FactSageTM 7.2.
A3_X1

\# inclusions=12 A. $F=25.31 \mathrm{ppm}$

B3_X1

\# inclusions=26 A. $F=14.94 \mathrm{ppm}$

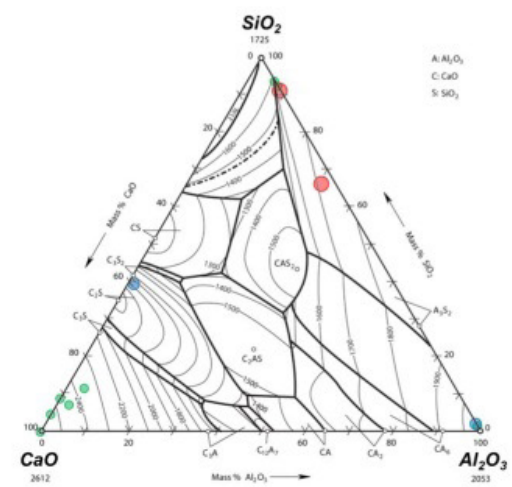

A3

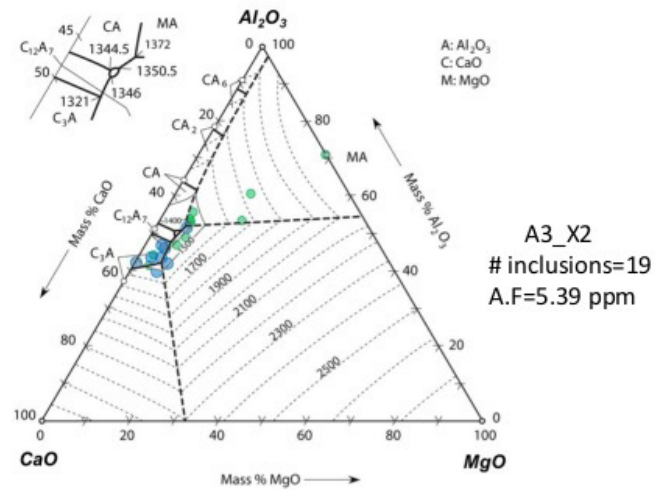

B3

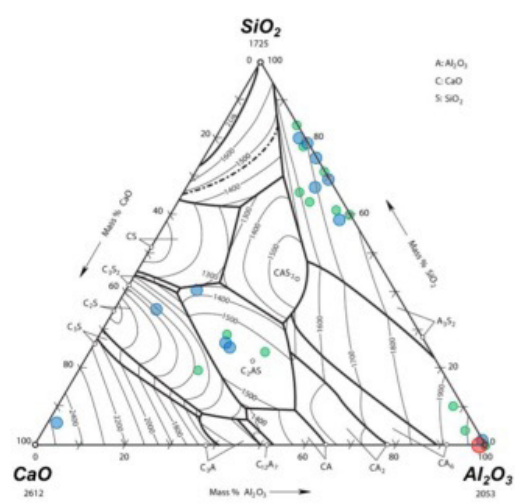

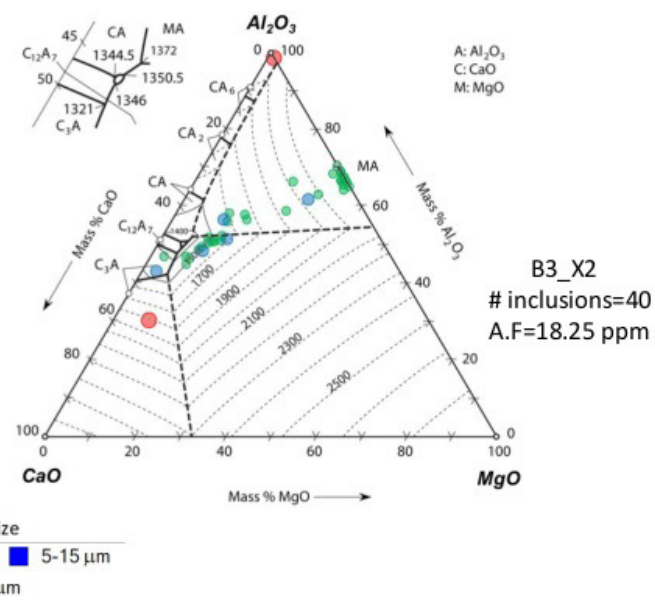

Figure 11. Distribution of composition, size and area fraction (AF) of inclusions in steel. Samples X1 (after vacuum) and X2 (in the tundish). Ternary diagrams $\mathrm{CaO}-\mathrm{SiO}_{2}-\mathrm{Al}_{2} \mathrm{O}_{3}$ (samples X1-after vacuum) and $\mathrm{CaO}-\mathrm{Al}_{2} \mathrm{O}_{3}-\mathrm{MgO}$ (samples X2-in the tundish) system. 


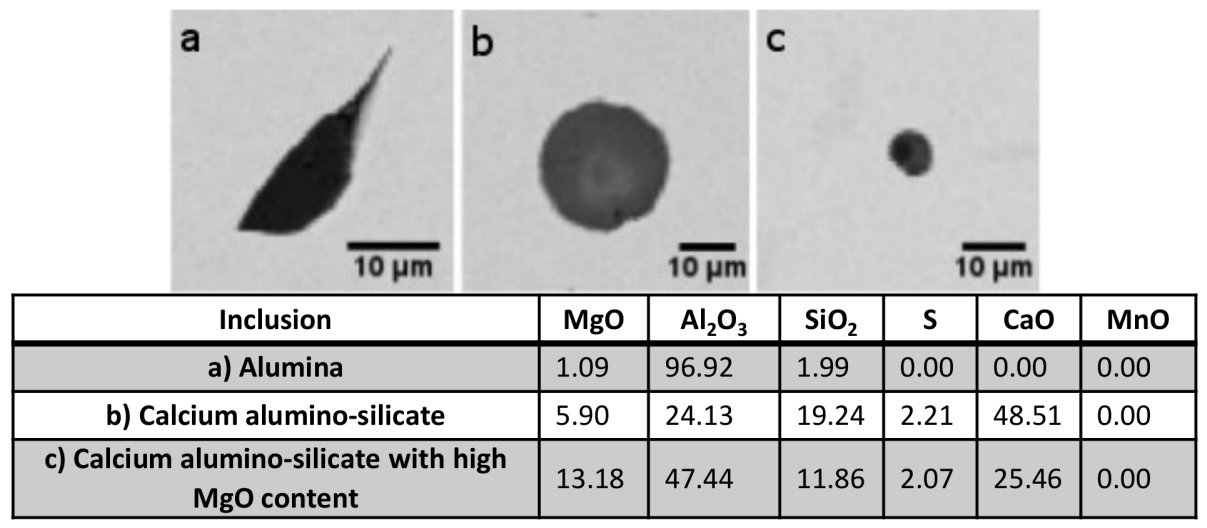

Figure 12. Morphology and typical inclusions of some heats analized.

the B3 heat, the inclusions were calcium alumino silicates and alumina after the vacuum. In the tundish, inclusions of spinel, complex and some inclusions in the liquid region are observed. As shown by Figure 11 in sample A3 X2 the $\mathrm{MgO}$ is lower than in the condition shown by sample B3_X2, this suggests the formation of $\mathrm{MgO}$ (spinel) rich inclusions.

Some typical morphologies of inclusions found in these heats are shown in Figure 12. The types of inclusions observed are based in alumina and calcium aluminate silicate as well as by calcium aluminate silicate with high $\mathrm{MgO}$ content.

\section{Conclusions}

From analyzing the results of the heats, we conclude:

- The consecutive reduction of $\mathrm{MgO}$ and $\mathrm{CaO}$ in the slag by $\mathrm{Al}$ confirms the increase of $[\mathrm{Mg}]$ and $[\mathrm{Ca}]$ dissolved in the liquid steel.

- $\quad$ The $\mathrm{MgO}$ in the inclusions was affected by slag composition (reduction of the $\% \mathrm{FeO}$ oxides content, increase of the $\mathrm{CaO} / \mathrm{SiO}_{2}$ (binary basicity) and $\mathrm{CaO} / \mathrm{Al}_{2} \mathrm{O}_{3}$, decrease of the silica content and increment liquid fraction in the slag), keeping in good accordance to references.

- For all heats analyzed, their phase stability diagrams suggest the formation of spinel inclusions according to the contents of $[\mathrm{Mg}]$ and $[\mathrm{Al}]$ in the molten steel. Significant reduction will occur with the increase of the content of $\mathrm{Mg}$ in molten steel greater than about $10 \mathrm{ppm}$ in the range of $89-130 \mathrm{ppm}$ [Al].

- A calcium deficit minimum of $1 \mathrm{ppm}$ and maximum of $6 \mathrm{ppm}$ in the heats was responsible for the low transformation of the spinel inclusions during the process.

- During the final step (X2) of the steelmaking process there is a possibility that re-oxidation events occurred, verified by increases in the density of inclusions or total oxygen (TO) values.

- The best performance for 52100 steel production was the $\mathrm{A} 3$ heat, considering the composition of the slag $\left(\mathrm{CaO} 48.31 \%, \mathrm{Al}_{2} \mathrm{O}_{3} 15.43 \%, \mathrm{SiO}_{2} 17.08 \%\right.$, $\mathrm{MgO} 15.79$, binary basicity 2.8, C/A slag ratio 2.7, liquid fraction $75 \%$ ) and inclusion composition in steel $(\mathrm{C} / \mathrm{A})$ in the value of 0.88 .

\section{Acknowledgements}

The authors are grateful to: Dr. Prof. Nestor Heck (computational thermodynamics group) for discussing and calculating the phase stability diagram. Also to the CNPq (National Council for Scientific and Technological Development) and FLE (Luiz Englert Foundation) for their financial support.

\section{References}

1. Costa e Silva A. Non-metallic inclusions in steels - origin and control. J Mater Res Technol. 2018;7(3):283-99.

2. Bhadeshia HKDH. Steels for bearings. Prog Mater Sci. 2012;57(2):268-435.

3. Zheng L, Xu M. ASTM STP 1465: study of vacuum carbondeoxidization of high carbon chromium bearing Steel. Bearing steel technology: advances and state of the art in bearing steel quality assurance . 7th ed. West Conshohocken, PA: ASTM; 2007. p. 19-24.

4. Monnot J, Heritier B, Cogne JY. ASTM STP 987: effect of steel manufacturing processes on the quality of bearing steels. Philadelphia: American Society for Testing and Materials; 1988. p. 149-65, 268-92.

5. Nishikawa T, Nagayama H, Nishimon S, Asai K, Fujii I, Sugimoto T. Study of evaluating method for non-metallic inclusions and development of slag refining for bearing steel - improvement of nonmetallic inclusion. bearing steel technologies: developments in bearing steel quality assessment and correlations with bearing life - ASTM STP 1419. In: Beswick JM, editors. Bearing steel technology: advances and state of the art in bearing steel quality assurance. West Conshohocken, PA: ASTM; 2002. p. 160-63.

6. Tsubota K, Sato T, Kato Y, Hiraoka K, Hayashi R. Bearing steels in the 21st century. In: Hoo JJC, Green WB, editors. Bearing steels: into the 21 st century - ASTM STP 1327 . West Conshohocken, PA: ASTM; 1998. p. 202-15.

7. Uesugi T, Tsubota K. Quality of high-carbon chromium bearing steel produced in the electric arc furnace-ladle furnace - RH vacuum degassing vessel—vertical continuous caster. In: Hoo J JC, editors. Effect of steel manufacturing processes on the quality of bearing steels- ASTM STP 987. Philadelphia: American Society for Testing and Materials; 1988. p. 278-292.

8. Kawakami K, Takada S, Takasu I, Nakashima K. Clean and reliable bearing steel. In: ICS Proceedings; 2005; Charlotte. Proceedings. USA: Kyushu Univeristy. p. 209-20. 
9. Valdez M, Shannon GS, Sridhar S. The ability of slags to absorb solid oxide inclusions. ISIJ Int. 2006;46(3):450-7.

10. Capurro C, Cerrutti G, Cicutti C, Liz C, Bilancieri A, Traini P. Effect of vacuum treatment on liquid steel inclusion population. In: 20th IAS Steel Conference; 2014 Nov 4-6; Rosário, Argentina. Proceedings. USA: IAS. p. 60-70.

11. Deng Z, Miao-yong Z, Bao-jun Z, Yong-gang D. Effect of basicity on deoxidation capability of refining slag. J Iron Steel Res Int. 2013;20(2):21-6.

12. Kim SJ, Harada A, Kitamura S. Condition to suppress spinel formation in ladle treatment predicted by the kinetic simulation model. In: AISTech Proceedings; Cleveland, Ohio, USA; 2015 May 4-7. Proceedings. Warrendale: Association for Iron \& Steel Technology. p. 3261-71.

13. Kang Y, Li F, Morita K, Sichen D. Mechanism study on the formation of liquid calcium aluminate inclusion from $\mathrm{MgO}-$ $\mathrm{Al}_{2} \mathrm{O}_{3}$ spinel. J Iron Steel Res Int. 2006;77:785-92.

14. Deng Z, Zhu M. Evolution mechanism of non-metallic inclusions in Al-Killed alloyed steel during secondary refining process. ISIJ Int. 2013;3(53):450-8.

15. Okuyama G, Yamaguchi K, Takeuchi S, Sorimachi K. Effect of slag composition on the kinetics of formation of $\mathrm{Al}_{2} \mathrm{O}_{3}-\mathrm{MgO}$ inclusions in aluminum killed ferritic stainless steel. ISIJ Int. 2000;40(2):121-8.

16. Park JH, Todoroki H. Control of $\mathrm{MgO} \cdot \mathrm{Al}_{2} \mathrm{O}_{3}$ spinel inclusions in stainless steels. ISIJ Int. 2010;50(10):1333-46.

17. Yang S, Wang Q, Zhang L, Li J, Peaslee K. Formation and modification of $\mathrm{MgO} \cdot \mathrm{Al}_{2} \mathrm{O}_{3}$-based inclusions in alloy steels. Metall Mater Trans, B, Process Metall Mater Proc Sci. 2012;43:731-50.

18. Liu Y, Zhang Y, Zhang L, Ren Y, Shen P, Luo Y. Formation mechanism of complex oxide inclusions in $55 \mathrm{SiCr}$ spring steels. Steel Res Int. 2018;8(9):1-11.

19. Wang H, Li J, Shi C-B, Li J. Evolution of $\mathrm{Al}_{2} \mathrm{O}_{3}$ inclusions by magnesium treatment in $\mathrm{H} 13$ hot work die steel. Ironmak Steelmak. 2017;44(2):128-33.

20. Tang H, Wang Y, Wu G, Lan P, Zhang J. Inclusion evolution in 50CrVA spring steel by optimization of refining slag. J Iron Steel Res Int. 2017;24:879-87.

21. Zhang L, Ren Y, Duan H, Yang W, Sun L. Stability diagram of $\mathrm{Mg}$-Al-O system inclusions in molten steel. Metall Mater Trans, B, Process Metall Mater Proc Sci. 2015;46B:1809-25. http://dx.doi.org/10.1007/s11663-015-0361-7.

22. Costa e Silva A. Calcium and magnesium thermodynamics in steel and its impacts on secondary steelmaking: a computational thermodynamics approach. Revue de Metallurgie Cahiers D’Informations Techniques. 2008;105(4):181-93.

23. Jiang $\mathrm{M}$, Wang $\mathrm{X}$, Chen $\mathrm{B}$, Wang W. Formation of $\mathrm{MgO} \cdot \mathrm{Al}_{2} \mathrm{O}_{3}$ inclusions in high strength alloyed structural steel refined by $\mathrm{CaO}-\mathrm{SiO}_{2}-\mathrm{Al}_{2} \mathrm{O}_{3}-\mathrm{MgO}$ slag. ISIJ Int. 2008;48(7):885-90.

24. Capurro C, Cerrutti G, Cicutti C. Study of the generation and modification of spinel type inclusions during secondary metallurgy and casting stages. In: 19th IAS Steelmaking Conference; Argentine; 2013 November. Proceedings. USA: Industrial Heating; 2013. p. 332-41.

25. Bartosiaki BG, Pereira JAM, Bielefeldt WV, Vilela ACF. Estudo de inclusões não-metálicas em aços durante tratamento em desgaseificador a vácuo e início do lingotamento contínuo. In: 45th ABM Melt shop Congress, Porto Alegre, RS, Brazil; 2014 May 25-28. Proceedings. São Paulo: ABM.

26. Kaushik P, Yin H. Thermodynamics, engineering and characterization of inclusions in advanced high strength steels. In: 8th International Conference on Clean Steel; Budapest, Hungary; 2012 May. Proceedings. Budapest: OMBKE

27. Yang $G$, Wang $X$. Inclusion evolution after calcium addition in low carbon al-killed steel with ultra low sulfur content. ISIJ Int. 2015;55(1):126-33.

28. Reis BH, Bartosiaki BG, Pereira JAM, Bielefeldt WV, Vilela ACF. Characterization and study of the formation, treatment and removal of non-metallic inclusions in SAE 52100 steel. In: 19th IAS Steel Conference; Argentine; 2013. Proceedings. USA: Industrial Heating; 2013.

29. Julio AMP, Cardoso da Rocha V, Yoshioka A, Bielefeldt WV, Antônio CFV. Analysis of secondary refining slag parameters with focus on inclusion cleanliness. Mater Res. 2018;21(5):1-11.

30. FACTSAGE. [homepage on the Internet]. [cited 2019 Oct 8]. Available from: http://www.factsage.com/

31. Suito H, Inoue R. Thermodynamics on control of inclusions composition in ultraclean steels. ISIJ Int. 1996;36(5):528-36.

32. Malayeri KR, Olund P, Sjoblom U. Thermodynamic calculations versus instrumental analysis of slag-steel equilibria in an aSEASKF ladle furnace. In Beswick JM, editors. Advances in steel technologies for rolling bearings. West Conshohocken: ASTM International; 2015. p. 16-26. Bearing Steel Technologies: 10th volume. http://dx.doi.org/10.1520/STP158020140025.

33. Jiang M, Wang X, Chen B, Wang W. Laboratory study on evolution mechanisms of non-metallic inclusions in high strength alloyed steel refined by high basicity slag. ISIJ Int. 2010;50(1):95-104

34. Wen Y, Lifeng Z, Xinhua W, Ying R, Xuefeng L, Shan Q. Characteristics of inclusions in low carbon al-killed steel during ladle furnace refining and calcium treatment. ISIJ Int. 2013;53(8):1401-10.

35 Chunyang L, Xu GAO, Shigeru U, Shin-ya K. Change in composition of inclusions through the reaction between $\mathrm{Al}$ killed steel and the slag of $\mathrm{CaO}$ and $\mathrm{MgO}$ saturation. 2018. http://dx.doi.org/10.2355/isijinternational.ISIJINT-2018-584.

36. Jiang $M$, Wang $X H$, Wang WJ. Study on refining slags targeting high cleanliness and lower melting temperature inclusions in Al killed steel. Ironmak Steelmak. 2012;39(1):20-5.

37. Ma WJ, Bao YP, Wang M, Zhao DW. Influence of slag composition on bearing steel cleanness. Ironmak Steelmak. 2014;41(1):26-30

38. Mendez J, Gómez A, Capurro C, Donayo R, Cicutti C. Effect of process conditions on the Evolution of $\mathrm{MgO}$ content of inclusions during the production of calcium treated, aluminum killed steels. In: 8th International Conference on Clean Steel; 2012 May 14-16; Budapest, Hungary; Proceedings. Budapest: OMBKE; 2012.

39. Tang YU. Effect of slag composition on inclusion control in LF-VD process for ultra-low oxygen alloyed structural steel. Procedia Earth and Planetary Science. 2011;2:89-97.

40. $\mathrm{Mu} \mathrm{H}$, Webler BA, Fruehan RJ. Reduction of slags and refractories by $\mathrm{Al}$ in steel and inclusion modification. In: AISTech Proceedings; 2015 May 4-7; Cleveland, Ohio, USA. Proceedings. Warrendale: Association for Iron \& Steel Technology; 2015. p. 3272-278.

41. Bao S, Wang X, Zhang L, Yang S, PeasleeK. Improving steel cleanliness through slag refining. In: AISTech 2008 - Iron and Steel Technology Conference; 2008 May 5-8; Pittsburgh, PA, USA. Proceedings. Minneapolis: Faculty Research \& Creative Works; 2008.

42. Takayuki N, Kaoru S. Introduction to formation of spinel inclusions in molten stainless steel under Al deoxidation with slags. Tetsu To Hagane. 1998;84(12):837.

43. Tang H, Li J. Thermodynamic analysis on the formation mechanism of $\mathrm{MgO} \cdot \mathrm{Al}_{2} \mathrm{O}_{3}$ spinel type inclusions in casing steel. Int J Miner Metall Mater. 2010;17(1):32. http://dx.doi. org/10.1007/s12613-010-0106-1.

44. Todoroki H, Mizuno K. Effect of silica in slag on inclusion compositions in 304 stainless steel deoxidized with aluminum. ISIJ Int. 2004;44(8):1350-7.

45. Shin JH, Chung Y, Park JH. Refractory-slag-metal-inclusion multiphase reactions modeling using computational thermodynamics: kinetic model for prediction of inclusion evolution in molten steel. Metall Mater Trans, B, Process Metall Mater Proc Sci. 2017;48b:46-59.

46. Jun Y, Xin-hua W, Min J, Wang-yun W. Effect of calcium treatment on non-metallic inclusions in ultra-low oxygen steel 
refined by high basicity high $\mathrm{Al}_{2} \mathrm{O}_{3}$ slag. J Iron Steel Res Int. 2011;18(7):8-14.

47. Tan J, Webler BA. Reoxidation of inclusions after aluminum deoxidation and calcium treatment. In: AISTech Proceedings; 2015; Cleveland, Ohio, USA. Proceedings. Warrendale: Association for Iron \& Steel Technology; 2015. p. 3296-304.

48. Alves PC, Pereira JAM, Rocha VC, Bielefeldt WV, Vilela ACF. Laboratorial analysis of inclusions formed by reoxidation in tundish steelmaking. Steel Res Int. 2018;89(11). http://dx.doi. org/10.1002/srin.201800248.

49. Zhiyin DENG, Miaoyong ZHU. Evolution mechanism of nonmetallic inclusions in Al-killed alloyed steel during secondary refining process. ISIJ Int. 2013;53(3):450-8.

50 Kang YJ, Li F, Morita K, Sichen D. Mechanism study on the formation of liquid calcium aluminate inclusion from $\mathrm{MgO}$. AI203 spinel. Steel Research Int. 2006;77(11):785-92.

51. Shu-feng Y, Jing-she L, Li-feng Z, Peaslee K, Zai-fei W. Behavior of $\mathrm{MgO} \cdot \mathrm{Al}_{2} \mathrm{O}_{3}$ based inclusions in alloy steel during refining process. J Iron Steel Res Int. 2010;17(7):1-6.

52. Yanyan BI, Karasev AV, Jönsson PG. Evolution of different inclusions during ladle treatment and continuous casting of stainless steel. ISIJ Int. 2013;53(12):2099-109.

53. Jiang M, Wang X, Chen B, Wang W. Laboratory study on evolution mechanisms of non-metallic inclusions in high strength alloyed steel refined by high basicity slag. ISIJ Int. 2010;50(1):95-104.

54. Verma N, Pistorius PC, Fruehan RJ, Potter MS, Oltmann HG, Pretorius EB. Calcium modification of spinel inclusions in aluminum-killed steel: reaction Steps. Metall Mater Trans, B, Process Metall Mater Proc Sci. 2012;43:830-956.

55. Geldenhuis JMA, Pistorius PC. Minimisation of calcium additions to low carbon steel grades. Ironmak Steelmak. 2000;27(6):442-9.

56. Deepoo Kumar P, Pistorius C. A study on calcium transfer from slag to steel and its effect on modification of alumina and spinel inclusions. Advances in molten slags, fluxes, and salts. In: Reddy RG, Chaubal P, Chris Pistorius P, Pal U, editors. 10th International Conference on Molten Slags, Fluxes and Salts (MOLTEN16); 2016; USA. Proceedings. USA: The Minerals, Metals \& Materials Society - TMS; 2016. p. 145-53.

57. Kumar D, Pistorius PC. Rate of $\mathrm{MgO}$ pickup in alumina inclusions in aluminum-killed steel. Metall Mater Trans, B, Process Metall Mater Proc Sci. 2019;50B:181-91.

58. Chris Pistorius P, Peter Presoly K, Tshilombo G. Magnesium: origin and role in calcium-treated inclusions. In: Sohn International Symposium Advanced Processing of Metals and Materials; 2006; USA. Proceedings. USA: TMS; 2006. p. 373-78. V. 2: Thermo and Physicochemical Principles: Iron and Steel Making.

59. Bielefeldt WV, Vilela ACF. Computational thermodynamic study of inclusions formation in the continuous casting of SAE 8620 steel. Steel Res Int. 2010;81(12):1064-9.

60. Lino RE, Marins ÂMF, Marchi LA, Mendes JA, Penna LV, Costa No JG, et al. Influence of the chemical composition on steel casting performance. JMR\&T. 2017;6(1):50-6. 